\title{
ANALISIS FINANSIAL HASIL HUTAN BUKAN KAYU (HHBK) KARET DAN DURIAN DI KABUPATEN SIAK
}

\author{
Enny Insusanty, Ambar Tri Ratnaningsih, dan Sri Rahayu Prastyaningsih \\ Dosen Fakultas Kehutanan Universitas Lancang Kuning \\ JIn. Yos Sudarso Km. 8 Rumbai Pekanbaru Riau \\ Email: annovisa@yahoo.com,ambar_trn@yahoo.com dan srirahayu_pn@yahoo.co.id
}

\begin{abstract}
Non-Timber Forest Products (NTFPs) are part of an ecosystem that has diverse roles both for the natural environment and for humans. NTFPs that are commonly used and commercialized include sandalwood, sap, gaharu, sago, rattan, aren, bamboo, medicinal plants and fruit plants. The purpose of this research is to perform financial analysis and feasibility of HHBK especially rubber and durian. The method used is survey method with purposive sampling to rubber farmer and durian in Siak Regency. The analysis of research data is descriptively qualitative. The results showed that rubber value of NPV Rp 7.076.819.809, -, BCR 2.24 and IRR $15.09 \%$ while durian has NPV Rp 738.553.324, - BCR 2.00 and IRR 13.67\%. Based on the criteria of financial feasibility indicators can be concluded that the rubber cultivation and durian business financially feasible to be developed
\end{abstract}

Keywords: financial analysis, rubber, durian

\section{PENDAHULUAN}

\section{Latar Belakang}

Paradigma baru sektor kehutanan memandang sumber daya hutan mempunyai potensi multi fungsi yang dapat memberikan manfaat ekonomi, lingkungan dan sosial bagi kesejahteraan umat manusia. Sumber daya hutan juga bersifat multi guna dan memuat multi kepentingan serta pemanfaatannya diarahkan untuk mewujudkan sebesar-besarnya kemakmuran rakyat. Manfaat tersebut bukan hanya berasal dari Hasil Hutan Kayu yang hanya memberikan sumbangan 20\%, melainkan juga manfaat hasil hutan bukan kayu (HHBK) dan jasa lingkungan (pemanfaatan aliran air, pemanfaatan air, wisata alam, perlindungan keanekaragaman hayati, penyelamatan dan perlindungan), yang memberikan sumbangan terbesar yakni $80 \%$, namun hingga saat ini potensi HHBK tersebut belum dapat dimanfaatkan secara optimal (Anonim, 2009). Paradigma ini makin menyadarkan kita bahwa produk HHBK merupakan salah satu sumber daya hutan yang memiliki keunggulan komparatif dan paling bersinggungan 
dengan masyarakat sekitar hutan. HHBK terbukti dapat memberikan dampak pada peningkatan penghasilan masyarakat sekitar sehingga berkontribusi terhadap kejahteraan masyarakat.

Hasil Hutan Bukan Kayu (HHBK) merupakan bagian dari ekosistem yang memiliki peranan yang beragam, baik terhadap lingkungan alam maupun bagi manusia. HHBK yang sudah biasa dimanfaatkan dan dikomersilkan diantaranya adalah cendana, gaharu, sagu, rotan, aren, bambu, tanaman obat dan tanaman buah-buahan.

Kabupaten Siak memiliki potensi HHBK yang cukup besar diantaranya, buah-buahan, karet, rotan dan juga lebah madu yang tersebar di beberapa kecamatan sebagai sentranya. Untuk tanaman buah-buahan dengan produk unggulan adalah durian terdapat di Kecamatan Mempura. Buah durian yang ada diperoleh dari pohon durian yang sudah berumur 50-70 tahun. Sehingga jika terjadi musim durian maka pendapatan masyarakat desa akan ditambah dari hasil penjualan buah durian. Selain rasanya yang enak buah durian juga memiliki harga yang cukup mahal sehingga memberikan kontribusi pendapatan bagi masyarakat. Tanaman karet secara umum tersebar merata di setiap Kecamatan di kabupaten Siak. Potensi Hasil Hutan Non Kayu dari getah karet akan memberikan nilai tambah bagi petani.

Pemanfaatan karet sebagai salah satu mata pencaharian utama masyarakat memiliki nilai ekonomi dan durian sebagai buah yang banyak diminati dan memiliki nilai jual cukup baik maka perlu dilakukan kajian mengenai analisis finansial HHBK khususnya karet dan durian di Kabupaten Siak. Adapun tujuan penelitian ini adalah menganalisis potensi dan analisis kelayakan finansial Hasil Hutan Bukan Kayu (HHBK) karet dan durian di Kabupaten Siak.

\section{METODE PENELITIAN \\ Waktu dan Tempat}

Penelitian dilakukan di Kabupaten Siak selama 6 bulan yaitu pada bulan Desember 2016 sampai dengan bulan Juni 2017. Adapan lokasi penelitian tersebar dibeberapa lokasi yaitu Desa Kampung Tengah Kecamatan Mempura dan Desa Kuala Gasib Kecamatan Koto Gasib.

\section{Alat dan Bahan Penelitian}

Bahan yang digunakan pada penelitian ini adalah kuisioner yang 
merupakan kumpulan pertanyaan yang akan diajukan. Sedangkan alat yang digunakan berupa alat-alat tulis, komputer, kalkulator, kamera.

Jenis Data dan Metode Pengumpulan Data

Untuk mengumpulkan data primer maka dilakukan kuisioner, wawancara dan observasi langsung di lapangan yang meliputi harga jual HHBK dan biaya HHBK. Sedangkan untuk mengumpulkan data sekunder dilakukan studi literatur dari BPS, monografi desa, Kementrian Kehutanan dan laporan penelitian. Sedangkan data primer diperoleh dengan menggunakan kuisioner dari masyarakat yang mengambil HHBK yaitu, petani karet, dan durian

Penelitian ini dilakukan dengan metode survei kepada masyarakat yang memanfaatkan HHBK yang tersebar disentra produksi HHBK di Kabupaten Siak. Untuk mengetahui nilai ekonomi dari masing-masing HHBK dilakukan pengambilan data secara purposive sampling. Selain itu juga dilakukan kegiatan wawancara, baik wawancara dengan panduan kuesioner (daftar isian) maupun wawancara mendalam (indepth interview).

\section{Teknik Pengolahan Data}

\section{Analisis Kelayakan Finansial}

Analisis kelayakan finansial dilakukan untuk memperoleh gambaran mengenai kelayakan karet dan durian. Hal ini disebabkan kedua komoditi ini merupakan tanaman jangka panjang yaitu sampai 25 tahun dan 50 tahun sehingga perlu memperhatikan suku bunya dan kelayakan usaha. Beberapa parameter yang digunakan dalam hal ini adalah Net Present Value (NPV), Benefit Cost Ratio (BCR) dan Internal Rate of Return (IRR). NPV adalah nilai saat ini yang menggambarkan nilai keuntungan yang diperoleh selama periode pengusahaan dengan menghitung nilai waktu dari uang. Suatu usaha dikatakan menguntungkan untuk dilaksanakan jika memiliki nilai NPV yang positif. BCR merupakan perbandingan antara pendapatan dan pengeluaran selama periode pengusahaan (dengan memperhitungkan nilai waktu dari uang), sedangkan IRR adalah tingkat suku bunga tertinggi yang dapat dibayar oleh suatu proyek/usaha atau dengan kata lain merupakan kemampuan memperoleh pendapatan dari uang yang diinvestasikan. Suatu usaha dikatakan layak jika memiliki nilai IRR yang lebih besar dari tingkat suku bunga yang 
berlaku di pasar pada saat tersebut (Suharjito et al. 2003).

Nilai NPV, BCR dan IRR dapat dinyatakan dalam rumus sebagai berikut (Gittinger 1986; Suharjito et al. 2003):

$$
\begin{gathered}
N P V=\sum_{t=1}^{t=n} \frac{(B t-C t)}{(1+i)^{t}} \\
B C R=\frac{\sum_{t=1}^{t=n} \frac{B t}{(1+i)^{t}}}{\sum_{t=1}^{t=n} \frac{C t}{(1+i)^{t}}} \\
I R R=\sum_{t=1}^{t=n} \frac{(B t-C t)}{(1+i)^{t}}=0
\end{gathered}
$$

Keterangan:

NPV = Nilai Bersih Sekarang (Net

$$
\text { Present Value) }
$$

$\mathrm{BCR}=$ Rasio Pendapatan dan Biaya

(Benefit Cost Ratio)

$\mathrm{IRR}=$ Internal Rate of Return

$\mathrm{Bt}=$ Komponen Pendapatan pada

Tahun ke-t

$\mathrm{Ct}=$ Komponen Biaya pada Tahun ke-t

$\mathrm{t}=$ Tahun dari proyek

i = Suku bunga (Interest Rate)

$\mathrm{n}$ = Umur proyek investasi sampai tahun ke-n
HASIL DAN PEMBAHASAN

Potensi dan Analisis Finansial Karet di Kabupaten Siak

\section{1) Potensi Karet}

Karet merupakan salah satu komoditi penting, baik sebagai sumber pendapatan, kesempatan kerja dan devisa, pendorong pertumbuhan ekonomi sentra-sentra baru di wilayah sekitar perkebunan karet maupun pelestarian lingkungan dan sumberdaya hayati. Namun sebagai negara dengan luas areal terbesar dan produksi kedua terbesar dunia, Indonesia masih menghadapi beberapa kendala, yaitu rendahnya produktivitas, terutama karet rakyat yang merupakan mayoritas areal karet nasional dan ragam produk olahan yang masih terbatas, yang didominasi oleh karet remah (crumb rubber). Diperkirakan ada lebih dari 3,4 juta hektar perkebunan karet dilndonesia, $85 \%$ di antaranya (2,9 juta hektar) merupakan perkebunan karet yang dikelola oleh rakyat atau petani skala kecil, dan sisanya dikelola oleh perkebunan besar milik negara atau swasta.

Usaha kebun karet adalah salah satu mata pencarian utama masyarakat Desa Kuala Gasib, adapun status kepemilikan lahan adalah lahan milik 
sendiri. Untuk pembukaan lahan, tidak konstan. Pemasaran karet persiapan bibit dan penanaman dilakukan dengan menjual kepada sepenuhnya dikelola oleh individu, persiapan bibit dan penanaman setelah tanaman karet telah menghasilkan dengan jangka waktu selama 25 tahun.

Para petani karet dari Desa Kuala Gasib sangat mengandalkan karet sebagai mata pencaharian utama di Desa mereka. Produksi karet para petani karet dapat memanen karet dengan jumlah rata-rata $539 \mathrm{~kg}$ per bulan, dalam 1 tahun petani karet dapat menghasilkan $64.632 \mathrm{~kg} /$ tahun dengan rata - rata perorangnya $6,463 \mathrm{~kg} / \mathrm{tahun}$ dan total luas perkebunan karet di Desa Kuala Gasib adalah 232 ha dengan harga karet dipasaran saat penelitian mencapai Rp 10,000 /kg (Saputra, 2017). Dalam proses penyadapan karet, yang sering menjadi kendala adalah cuaca. Produksi getah karet paling baik dilakukan yaitu saat musim panas. Getah karet akan sulit dipanen jika dalam kondisi cuaca hujan. Oleh sebab itu, para petani karet akan merasa kekurangan pemasukan untuk menghidupi keluarganya jika tidak dapat memproduksi getah karet.

Adanya fluktuasi harga jual karet yang tidak menentu menyebabkan keuntungan yang diperoleh petani juga pengumpul atau tengkulak sesuai harga yang telah ditetapkan. Menurut Marampa dan Maskan (2013) menyatakan peran tengkulak dalam monopoli harga karet menyebabkan harga ditingkat petani menjadi lebih rendah dan mengikat petani dengan memberikan pinjaman di awal sehingga posisi petani lemah.

\section{2) Analisis Kelayakan Finansial Karet}

Luas areal yang dimanfaatakan untuk pengembangan tanaman karet adalah 232 ha. Areal yang akan dimanfaatakan untuk pengembangan tanaman karet merupakan milik petani yang dikelola dengan luasan beragam. Pengembangan tanaman karet sebagai tanaman kehidupan dilakukan untuk meningkatkan kesejahteraan petani.

Adapun asumsi dalam penelitian ini didasarkan penjelasan berikut ini:

1. Luas total hutan yang akan dibangun karet 232 ha.

2. Umur proyek yang diusulkan adalah 25 tahun.

3. Jangka waktu penilaian kelayakan Usaha Tanaman Karet selama 25 tahun, umur panen tanaman untuk produksi getah pada tahun ke 7 (tujuh). 
4. Biaya untuk persemaian dan pembibitan karet sebesar Rp 3000/batang, pembersihan lahan Rp 600.000/ha, penyiapan lahan Rp 2000.000/ha, biaya penanaman $\mathrm{Rp}$ 1.700.000/ha, biaya perawatan 1.200.000/ha.

5. Upah tenaga kerja karet Rp. $70.000,-/ H O K$.

6. Karena investasi bersifat jangka panjang (tahun jamak), maka untuk menilai manfaat yang akan diperoleh dari proyek dan biaya yang dikeluarkan semuanya dinilai pada saat ini (present value) atau biasa disebut di diskon (discounted). Untuk keperluan tersebut maka dibutuhkan faktor diskonto (discount factor). Diskon faktor yang digunakan pada kajian ini dihitung pada tingkat suku bunga riil (i) $5 \%$. Nilai suku bunga riil diperoleh dengan mengurangkan nilai inflasi terhadap suku bunga deposito.

Dengan berlandaskan pada asumsi-asumsi di atas, analisis dimulai dengan memperkirakan jumlah pendapatan yang akan diperoleh dan mendaftar jenis-jenis biaya yang dibutuhkan. Secara umum terdapat tiga kategori biaya, yaitu: biaya investasi langsung, biaya investasi tetap dan biaya operasional. Biaya investasi langsung adalah biaya yang terkait dengan volume atau luas tanaman karet yang akan dibangun yang mencakup, penyiapan lahan, penanaman, persemaian dan pembibitan, serta pemeliharaan. Adapun, biaya investasi tetap meliputi sarana dan prasarana. Sedangkan biaya operasional terdiri dari biaya perawatan dan perlindungan tanaman.

Biaya investasi langsung yang diperlukan dalam pengelolaan karet dengan luasan 232 ha dengan rata-rata tingkat kepemilikan lahan petani adalah 2 ha disajikan pada tabel 1 . 


\section{Tabel 1. Biaya Investasi Langsung Karet}

\begin{tabular}{|c|l|c|c|c|}
\hline No & Biaya Investasi Langsung & Satuan & Harga/unit & Total Biaya \\
\hline 1 & Persemaian dan Pembibitan & $\mathrm{Rp} / \mathrm{btg}$ & 3.000 & 1.159 .998 .000 \\
\hline 2 & Land Clearing & $\mathrm{Rp} / \mathrm{Ha}$ & 600.000 & 139.200 .000 \\
\hline 3 & Penyiapan Lahan & $\mathrm{Rp} / \mathrm{Ha}$ & 2.000 .000 & 464.000 .000 \\
\hline 4 & Penanaman & $\mathrm{Rp} / \mathrm{Ha}$ & 1.700 .000 & 394.400 .000 \\
\hline 5 & Perawatan & $\mathrm{Rp} / \mathrm{Ha}$ & 1.200 .000 & 278.400 .000 \\
\hline & Jumlah & & & $\mathbf{2 . 0 4 1 . 5 9 8 . 0 0 0}$ \\
\hline & Rata -rata/ ha & & $\mathbf{8 . 7 9 9 . 9 9 1}$ \\
\hline
\end{tabular}

Biaya persemaian dan pembibitan dilakukan pada tahun pertama dengan jumlah bibit yang ditanam sebanyak 1.159.998.000 batang atau 386.666 batang /ha. Untuk kegiatan land clearing dilakukan pada tahun ke 2 demikian juga halnya dengan kegiatan penyiapan lahan dan penanaman. Untuk kegiatan perawatan dilakukan mulai tahun ke dua sampai dengan masa akhir periode. Untuk biaya investasi langsung per ha diperoleh $\mathrm{Rp}$ 8.799.991 yang merupakan modal awal yang dikeluarkan petani dalam kegiatan usaha tani karet. Biaya investasi tetap berupa peralatan yang diperlukan dalam usaha tani karet dari pra tanam sampai karet dapat dipanen sebesar Rp. 1.624.000,--. Sedangkan biaya tanam sampai produksi pertama pada tahun ke - 7 sebesar Rp 16.006.991/ha.

Berdasarkan produksi yang dihasilkan yang tanaman karet bardasarkan dari produksi sadapan karet mentah (Lumb), tanaman karet mulai menghasilkan pada saat berumur 7 tahun sampai 25 tahun dengan ratarata produksi $1800 \mathrm{~kg} / \mathrm{ha} / \mathrm{th}$, dengan rata-rata pendapatan per bulan $\mathrm{Rp}$. $1.350 .000 /$ ha.

Nilai taksiran pendapatan dan biaya yang dikeluarkan selama jangka waktu pengusahaan, selama 25 tahun, yang dihitung berdasarkan nilai-nilai asumsi yang telah diutarakan di muka, diperoleh nilai NPV sebesar Rp. 7.076.819.809 ,- (Tabel 2). Nilai tersebut mengindikasikan bahwa pada tingkat suku bunga riil $5 \%$, proyek pembangunan hutan tanaman sagu secara finansial dapat menguntungkan. Bahkan, jika kita perhatikan tingkat suku bunga riil pada lima tahun terakhir, ratarata hanya $1,22 \%$, jauh di bawah nilai suku bunga riil yang digunakan pada analisis ini. Dengan kata lain, jika dana yang tersedia tidak digunakan untuk investasi dalam bentuk tanaman karet, melainkan didepositokan ke bank, maka nilai keuntungan dari bunga deposito 
jauh lebih kecil dibandingkan dengan tanaman karet. Walaupun tingkat bunga deposito berdasarkan Bank Indonesia pada lima tahun terakhir rata-rata sebesar $7,44 \%$, namun nilai keuntungan tersebut tergerus oleh nilai inflasi yang menurut hasil perhitungan selama lima tahun terakhir mencapai rata-rata 6,22 \%. Dengan demikian, tanaman karet karet lebih menguntungkan.

Discount rate merefleksikan opportunity cost dari modal yang ditanamkan atau suku bunga pinjaman. Discount rate dapat menggunakan suku bunga pinjaman, suku bunga simpanan atau suku bunga riil sesuai dengan asumsi sumber modal yang digunakan. Namun begitu, disarankan untuk penggunaan suku bunga rendah $6-12 \%$ untuk menilai usaha budidaya di negara berkembang (Gittinger,1984 dalam Khotimah dan Sutiono, 2013).

Perbandingan antara pendapatan dan biaya (benefit cost ratio, BCR) pun menunjukkan nilai 2,24 yang mengindikasikan bahwa proyek ini layak untuk dikembangkan. Demikian juga halnya dengan nilai IRR lebih tinggi dibandingkan nilai suku bunga riil, yaitu $15,90 \%$ (Tabel 2).
Tabel 2. Nilai Indikator Kelayakan Tanaman Karet

\begin{tabular}{|c|l|c|}
\hline No & $\begin{array}{l}\text { Parameter } \\
\text { Kelayakan }\end{array}$ & Nilai \\
\hline 1. & $\begin{array}{l}\text { Net Present } \\
\text { Value (NPV) }\end{array}$ & Rp. 7.076 .819 .809 \\
\hline 2. & $\begin{array}{l}\text { Benefit Cost } \\
\text { Ratio (BCR) }\end{array}$ & 2.24 \\
\hline & $\begin{array}{l}\text { Internal Rate } \\
\text { of Return } \\
\text { (IRR) }\end{array}$ & 15.90 \\
\hline
\end{tabular}

Sumber: Data Olahan (2017)

\section{3) Potensi dan Analisis Finansial Durian}

\section{Potensi Durian}

Durian merupakan salah satu tanaman yang banyak menghasilkan pendapatan bagi masyarakat setempat bahkan durian dari desa ini sudah terkenal di sekitar Kabupaten Siak karena buahnya yang sangat tebal isinya dan manis rasanya, serta bijinya yang kecil. Buah durian biasanya dijual secara eceran dan dijual disekitar pinggir jalan dekat pohon durian. Buah durian dijual kepada pedagang durian di sekitar desa, biasanya dijual dengan harga $\mathrm{Rp} 25.000$,- per buah.

Berdasarkan hasil penelitian, masyarakat umumnya menanam jenis buah-buahan di lahan pertanian karena 
bermanfaat ganda yaitu bisa dikonsumsi pribadi dan menambah pendapatan keluarga dari hasil penjualan hasil produk pertanian. Menurut Zega, dkk (2011) menyatakan bahwa umumnya bentuk pengusahaan lahan masyarakat adalah kebun campuran dan pekarangan dimana tanaman yang memberikan pendapatan yang berarti adalah kelompok buah-buahan, sehingga tidak heran jika masyarakat memanfaatkan lahan yang kosong dengan menanam buah-buahan.

Potensi buah durian di Desa Kampung Tengah dengan mencapai 236 batang yang dimiliki oleh 24 petani. Jumlah kepemilikan durian bervariasi dari 4 sampai 60 batang dengan ratarata kepemilihan 9,8 batang/orang. Berdasarkan wawancara dengan responden diperkirakan bahwa jumlah panen buah durian pada musim panen mencapai 11.800 buah pertahun. Adapun harga durian ditingkat petani bervariasi yaitu $\mathrm{Rp} 15.000$ untuk yang kecil, Rp 25.000 untuk yang sedang dan Rp. 50.000 untuk yang besar. Nantinya ditingkat pedagang akan menjual ke konsumen dengan harga $\mathrm{Rp} 25.000$ untuk yang kecil Rp 50,000 untuk yang sedang dan > Rp 75.000 untuk yang besar.
Produksi buah durian jauh menurun pada tiga tahun belakangan ini disebabkan faktor cuaca seperti kabut asap yang menyebabkan bunga durian menjadi rontok. Pengalihan fungsi lahan menjadi perkebunan dan pembukaan areal jalan di Kampung Tengah menyebabkan banyak pohon yang harus ditebang. Untuk peremajaan tanaman petani juga mengalami kendala seperti sulitnya tanaman baru untuk tumbuh dan berbuah.

\section{Analisis Kelayakan Finansial Durian}

Luas areal yang dimanfaatkan untuk pengembangan tanaman durian adalah 6 ha. Tanaman durian yang ditanam dimiliki oleh masyarakat desa secara turun temurun. Potensi tanaman durian ini cukup besar karena harga jual yang durian yang cukup baik. Namun kendala yang dihadapi adalah sulitnya tanaman ini untuk dibudidayakan oleh masyarakat dan panen durian yang tidak tentu setiap tahunnya. Masa produktif tanaman durian sampai usia 50 tahun sehingga pemanfaatan lahan selama 50 (lima puluh) tahun dari 2017 - 2067 adalah sebagai berikut :

Adapun asumsi dalam penelitian ini didasarkan penjelasan berikut ini: 
1. Luas total hutan yang akan dibangun karet 6 ha.

2. Umur proyek yang diusulkan adalah 50 tahun.

3. Jangka waktu penilaian kelayakan Usaha Tanaman Durian selama 50 tahun, umur panen tanaman untuk produksi buah pada tahun ke 15 (lima belas).

4. Biaya untuk persemaian dan pembibitan karet sebesar $\mathrm{Rp}$ 25000/batang, lahan $\mathrm{Rp} \mathrm{600.000/ha,} \mathrm{penyiapan}$ lahan $\quad \operatorname{Rp}$ 2000.000/ha, biaya penanaman $\mathrm{Rp}$ 1.000.000/ha, biaya perawatan 3.000.000/ha.

5. Upah tenaga kerja karet $\mathrm{Rp}$. 70.000,-/HOK.

6. Diskon faktor yang digunakan pada kajian ini dihitung pada tingkat suku bunga riil (i) $5 \%$. Nilai suku bunga riil diperoleh dengan mengurangkan nilai inflasi terhadap suku bunga deposito.

Komponen

biaya yang

dikeluarkan dari kegiatan penanaman durian terdiri dari biaya investasi langsung, biaya investasi tetap dan biaya operasional. Biaya investasi langsung adalah biaya yang terkait dengan volume atau luas tanaman karet yang akan dibangun. Biaya investasi langsung yang diperlukan dalam pengelolaan karet dengan luasan 6 ha disajikan pada Tabel 3.

\section{Tabel 3. Biaya Investasi Langsung} Durian

\begin{tabular}{|c|l|c|c|c|}
\hline No & $\begin{array}{l}\text { Investasi } \\
\text { Langsung }\end{array}$ & Satuan & $\begin{array}{c}\text { Harga } \\
\text { /unit }\end{array}$ & Total Biaya \\
\hline 1 & $\begin{array}{l}\text { Persemaian } \\
\text { dan } \\
\text { Pembibitan }\end{array}$ & $\mathrm{Rp} / \mathrm{btg}$ & 25.000 & 5.900 .000 \\
\hline 2 & $\begin{array}{l}\text { Land } \\
\text { Clearing }\end{array}$ & $\mathrm{Rp} / \mathrm{Ha}$ & 600.000 & 3.600 .000 \\
\hline 3 & $\begin{array}{l}\text { Penyiapan } \\
\text { Lahan }\end{array}$ & $\mathrm{Rp} / \mathrm{Ha}$ & 2.000 .000 & 12.000 .000 \\
\hline 4 & Penanaman & $\mathrm{Rp} / \mathrm{Ha}$ & 1.000 .000 & 6.000 .000 \\
\hline 5 & Perawatan & $\mathrm{Rp} / \mathrm{Ha}$ & 4.000 .000 & 24.000 .000 \\
\hline & Jumlah & & & $\mathbf{5 1 . 5 0 0 . 0 0 0}$ \\
\hline & $\begin{array}{l}\text { Rata- } \\
\text { rata/ha }\end{array}$ & & & $\mathbf{8 . 5 8 3 . 3 3 3}$ \\
\hline
\end{tabular}

Biaya pada tahun pertama yang dikeluarkan adalah biaya persemaian dan pembibitan dengan jumlah bibit yang ditanam sebanyak 236 batang seharga Rp 25.000. Kegiatan di tahun kedua terdiri dari land clearing penyiapan lahan dan penanaman. Untuk kegiatan perawatan dilakukan mulai tahun ke dua sampai dengan masa akhir periode. Untuk biaya investasi langsung per ha diperoleh Rp 8.583.333 yang harus dikeluarkan petani pada awal kegiatan penanaman durian 
Adapun, biaya investasi tetap meliputi sarana dan prasarana. Sedangkan biaya operasional terdiri dari biaya perawatan dan perlindungan tanaman. Biaya investasi tetap berupa peralatan dan pondok jaga. Pondok jaga dibuat oleh petani untuk menjaga tanaman durian apabila telah mulai menghasilkan buah. Buah yang diambil adalah buah yang jatuh dari pohon durian ketika musim durian tiba, sehingga pondok yang dibuat cukup kokoh terbuat dari kayu dan beratapkan seng. Dengan biaya satu unit pondok ini sebesar Rp 5.000.000,-

Pohon durian hanya berbuah
pada saat musim durian yang
diasumsikan 1 kali setahun
Berdasarkan produksi yang dihasilkan yang tanaman durian bardasarkan dari buah yang dapat dipanen rata-rata berumur 15 tahun sampai 50 tahun dengan rata-rata pendapatan $\mathrm{Rp}$ 750.000/pohon, dengan jumlah pohon durian yang ditanam sebanyak 236 batang, sehingga diperoleh pendapatan total per tahun adalah $\mathrm{Rp}$ 177.000.000.- .

Untuk nilai kelayakan tanaman durian dengan masa periode tanam selama 50 tahun dimana tanaman durian mulai menghasilkan di usia 15 tahun dapat dilihat pada Tabel 4 .

Tabel 4. Nilai Indikator Kelayakan Tanaman Durian

\begin{tabular}{|c|l|c|}
\hline No & $\begin{array}{c}\text { Parameter } \\
\text { Kelayakan } \\
\text { Proyek }\end{array}$ & Nilai \\
\hline 1. & $\begin{array}{l}\text { Net Present } \\
\text { Value (NPV) }\end{array}$ & Rp 738.553.324,-- \\
\hline 2. & $\begin{array}{l}\text { Benefit Cost } \\
\text { Ratio (BCR) }\end{array}$ & 2.00 \\
\hline 3. & $\begin{array}{l}\text { Internal Rate } \\
\text { of Return } \\
\text { (IRR) }\end{array}$ & 13.67 \\
\hline
\end{tabular}

Sumber: Data Olahan (2017)

Nilai taksiran pendapatan dan biaya yang dikeluarkan selama jangka waktu pengusahaan, selama 50 tahun, yang dihitung berdasarkan nilai-nilai asumsi yang telah diutarakan di muka, diperoleh nilai NPV sebesar Rp. 738.553.324,-. $\quad$ Nilai tersebut mengindikasikan bahwa pada tingkat suku bunga riil $5 \%$, proyek pembangunan hutan tanaman durian secara finansial dapat menguntungkan.

Senada dengan nilai NPV, nilai perbandingan antara pendapatan dan biaya (benefit cost ratio, BCR) pun menunjukkan nilai 2,00 yang mengindikasikan bahwa proyek ini layak untuk dikembangkan. Demikian juga halnya dengan nilai IRR lebih tinggi 
dibandingkan nilai suku bunga riil, yaitu $13,67 \%$.

\section{KESIMPULAN DAN SARAN}

\section{Kesimpulan}

Berdasarkan analisis kelayakan finansial dengan kriteria Net Present Value (NPV), Benefit Cost Ratio (BCR) dan Internal Rate of Return (IRR) menunjukkan bahwa karet dan durian layak untuk dijalankan. Hasil analisis karet menunjukkan NPV Rp 7.076.819.809,- , BCR 2,24 dan IRR $15,09 \%$. Sedangkan durian memiliki NPV Rp 738.553.324,- $B C R 2,00$ dan IRR $13,67 \%$

\section{Saran}

Nilai ekonomi yang cukup besar dari HHBK yaitu karet dan durian merupakan potensi yang besar untuk dikembangkan sehingga kegiatan budidaya dan pengembangan kedua komoditi ini dapat lebih diintensifkan.

\section{DAFTAR PUSTAKA}

Anonim, 2009. Permenhut Nomor P.19/Menhut-II/2009 tentang StrategiPengembangan Hasil Hutan Bukan Kayu Nasional. DepartemenKehutanan RI. Jakarta

Gittinger JP. 1986. Analisa Ekonomi Proyek-Proyek Pertanian.
Terjemahan dari: Economic Analysis of Agriculture. Sutomo S dan Mangiri K. UI Press, Jakarta.

Khotimah $\mathrm{H}$ dan Sutiono. 2014.

Analisis Kelayakan Finansial

Usaha Budidaya Bambu. Jurnal IImu Kehutanan Volume 8 No. 1

Marampa dan Maskan. 2013. Analisis Kelayakan Finansial Budidaya Tanaman Karet (Hevea Brasiliensis) Skala Rakyat Di Kampung Tering Seberang Kecamatan Tering Kabupaten Kutai Barat. Jurnal Agrifor Volume XIII Nomor 1

Saputra, A. 2017. Nilai Ekonomi Hasil Hutan Bukan Kayu di Kabupaten Siak (Studi kasus: Kecamatan Tualang, Kecamatan Mempura dan Kecamatan Koto Gasib). Skripsi Fakultas Kehutanan Universitas Lancang Kuning Pekanbaru

Suharjito D, Sundawati L, Suyanto, Rahayu SU. 2003. Bahan Ajaran 5: Aspek Sosial Ekonomi dan Budaya Agroforestri Bogor. World Agroforestry Centre (ICRAF) South Asia.

Zega, S.B., Purwoko, A., \& Martial, T. 2011. Analisis Pengelolaan Agroforestry dan Kontribusinya terhadap Perekonomian Masyarakat. Laporan Penelitian. USU. Medan. 